\title{
LIST APOSTOLSKI DUODECIMUM SAECULUM OJCA ŚWIĘTEGO ŚW. JANA PAWŁA II Z OKAZJI TYSIĄC DWUSETNEJ ROCZNICY SOBORU NICEJSKIEGO II

\author{
MIEJSCE IKONY W WIERZE I ROZUMIENIU \\ ŚW. JANA PAWŁA II
}

List Ojca Świętego św. Jana Pawła II Wielkiego napisany został w Rzymie 4 grudnia 1987 r., w dziesiątym roku pontyfikatu, w dniu liturgicznego wspomnienia św. Jana Damasceńskiego, kapłana i doktora Kościoła.

\section{WSTĘP}

Nauka i nauczanie, przekazane jako dziedzictwo św. Jana Pawła II, obejmują niemal wszystkie ważne dziedziny wiedzy i życia społecznego, które pasterz Kościoła wyjaśnia w świetle wiary. Kwestią szczególnie ważną w nauczaniu Karola Wojtyły jako kardynała, uczestnika Soboru Watykańskiego II i jako papieża była szeroko zarysowana perspektywa ekumeniczna. Wskazywał i podejmował wiele możliwych kierunków dialogu z różnymi religiami, a najbardziej znaczącą troską było porozumienie z Kościołem prawosławnym. Potwierdzają to wybrane w tym miejscu, z konieczności ograniczone, listy, spośród których jednym z wcześniejszych był list $A$ Concilio Constantinopolitano, napisany w trzecim roku pontyfikatu,

Prof. dr hab. Urszula Mazurczak, Katedra Historii Sztuki Średniowiecznej i Nowożytnej, Instytut Nauk o Sztuce, Katolicki Uniwersytet Lubelski Jana Pawła II; adres do korespondencji: Al. Racławickie 14, 20-950 Lublin; e- mail:urszula.mazurczak@kul.pl; ORCID: 0000-0002-9314-5094 
w roku 1981, w uroczystość Zwiastowania Pańskiego, 25 marca. Ten list ma znaczenie szczególne. Skierowany został do episkopatu Kościoła katolickiego na 1600 rocznicę I Soboru Konstantynopolitańskiego i na 1550 rocznicę Soboru Efeskiego z 431 r. (413-424). I sobór w Konstantynopolu był drugim soborem powszechnym Kościoła, na nim sformułowano Credo apostolskie, wyznanie wiary w Ojca, Syna i Ducha Świętego, aktualne do dzisiaj w liturgii jako wspólna modlitwa całego chrześcijaństwa (Hryniewicz, Karski i Paprocki). Pomimo ostrych podziałów Kościoła w jego historii, Credo jest niepodważalnym spoiwem dla wszystkich chrześcijan. List, jak określa sam Autor na początku dokumentu, ,jest refleksją teologiczną i wezwaniem pasterskim zrodzonym z głębi serca" (Jan Paweł II, A Concilio Constantinopolitano 413). Wspomnienie Soboru Konstantynopolitańskiego uświadamia ludziom wierzącym kończącego się drugiego tysiąclecia chrześcijaństwa trwanie wiary w Trzecią Osobę Trójcy Świętej, Ducha Świętego, Jego pochodzenie od Ojca, tajemnicę Boga w Jego absolutnej transcendencji i Syna zrodzonego z Dziewicy Maryi (413). Wspominając 1550 rocznicę Soboru Efeskiego z roku 431, papież podkreślił rangę chrystologiczną tamtego wydarzenia, wcielenie Syna Bożego i rolę Maryi Matki Boga, Theotokos. Na soborze tym wyjaśniona została tajemnica boskiej i ludzkiej natury Chrystusa, co stało się podstawą wszelkich wyobrażeń plastycznych, zarazem niestety późniejszych herezji i sporów o obrazy (415).

1.

Obszerne dokumenty, listy apostolskie św. Jana Pawła II są świadectwem podejmowanych z wielką wrażliwością kwestii historycznych, duszpasterskich, teologicznych, upamiętniających ważne wydarzenia w życiu Kościołów prawosławnego i katolickiego. Przykładami są listy: Mentre si intensificano do biskupów kontynentu europejskiego na temat stosunków między katolikami a prawosławnymi w nowej sytuacji Europy Środkowej i Wschodniej (31 maja 1991 r.) (368-374), Orientale lumen do duchowieństwa i wiernych w setną rocznicę listu apostolskiego Orientalium dignitas papieża Leona XIII (2 maja 1995 r.) (375-406), ważny dokument Ringraziamo Dio anche - rozumiany jako Deklaracja wspólna Ojca Świętego Jana Pawła II i Patriarchy Ekumenicznego Konstantynopola Bartłomieja I (29 czerwca 1995 r.) (407-409), Magno cum gaudio - z okazji 400-lecia unii brzeskiej, skierowany do Myrosława Ivana S.R.E. kardynała Lubacziwskiego, arcybiskupa większego Lwowa dla Ukraińców (25 marca 1995 r.) (502-504). Wśród wielu innych listów jako świadectw duchowej jedności Ojca Świętego z prawosławiem i historycznej wiedzy o losach tej części chrześcijaństwa jest List apostolski Anzitutto rendo z okazji 350-lecia Unii Użhorodzkiej (18 kwietnia 1996 r.) (505-511). Powołując się w tym 
miejscu tylko na wybrane listy Jana Pawła II, dostrzega się nadzwyczajną troskę papieża o sprawy jedności Kościołów wschodniego i łacińskiego, szacunek wobec tradycji patrystycznej i mądrości ojców wschodnich w dziele kształtowania się łacińskiej tradycji teologicznej, filozofii chrześcijańskiej oraz kultury i sztuki. Papież oddawał cześć wybitnym osobistościom i świętym: Janowi Damasceńskiemu, Bazylemu Wielkiemu oraz Cyrylowi i Metodemu. List apostolski Patres Ecclesiae na 1600-lecie śmierci św. Bazylego (2 stycznia 1980 r.) (568-586) i List apostolski Egregiae virtutis, ogłaszający świętych Cyryla i Metodego współpatronami Europy (31 grudnia 1980 r.), dopełniają ten pokaźny dorobek Ojca Świętego, jego dążenia ekumeniczne i podtrzymanie historycznego znaczenia wschodniej tradycji chrześcijańskiej.

Droga Karola Wojtyły w nauczaniu i kształtowaniu jedności wiernych zaznaczyła się już w okresie pełnienia godności biskupa krakowskiego i kardynała, który jako uczestnik obrad Soboru Watykańskiego II doświadczał żywej obecności ojców wschodnich w modlitwie i wspólnych pracach nad ustawami soborowymi. Doświadczenie to szczególnie owocowało w późniejszych kontaktach i działaniu papieskim. W roku 1991 papież mianował biskupów dla kościołów obrządku bizantyńskiego na zachodniej Ukrainie i w Rumunii, co wyjaśnił w liście Mentre si intensificano z 31 maja 1991 r., skierowanym do biskupów kontynentu europejskiego, na temat stosunków między katolikami i prawosławnymi w nowej sytuacji Europy Środkowej i Wschodniej (369). Wskazał na dziedzictwo tego Kościoła, w którym nieodłącznym ogniwem praktyk religijnych, słowa, modlitwy i pieśni był obraz. Jedność z kościołem prawosławnym w nauczaniu Karola Wojtyły stanowi dziedzinę wnikliwych badań naukowych i doświadczeń religijnych, które zaowocowały obszerną literaturą w skali badań światowych.

Przedmiotem naszej szczególnej refleksji naukowej, z konieczności w tym miejscu ograniczonej do zagadnień wybranych, jest list Ojca Świętego napisany z okazji 1200. rocznicy Soboru Nicejskiego Duodecimum saeculum, wielokrotnie analizowany pod względem znaczenia teologicznego, historycznych uwarunkowań i dokumentów ekumenicznych. Skierowany do biskupów całego świata, tym bardziej budzi zainteresowanie w kwestiach teologicznych, z którymi nierozłącznie związana jest wizualizacja postaci boskich i świętych. W historii religijności ta wizualizacja poddawana była wszelkim próbom stanowienia łączności z praktykami wiary. Obrazowanie postaci w reprezentacji i w historiach biblijnych było gruntownym problemem od początku kształtowania się dogmatyki chrześcijańskiej i tym samym 
sztuki. O doniosłości tego zagadnienia w historii świadczą stale na nowo podejmowane studia, w różnych aspektach ukazujące problem sztuki w pierwszych wiekach chrześcijaństwa, zarówno w kręgu cesarstwa łacińskiego, jak i greckiego. Wnikliwą i syntetyczną analizę podjął w swoim studium Duch liturgii Ojciec Święty Benedykt XVI, wskazując na liturgię jako źródło powiązania słowa i obrazu, tym samym racji wizualnego ukazywania postaci biblijnych (Ratzinger). Liturgia w rozważaniach autora, ówczesnego kard. Ratzingera, stanowi jeden z czterech wielkich kręgów tematycznych, który - jak stwierdza we wstępie - ,jest wydarzeniem kosmicznym - w niej modli się całe stworzenie, a my wraz z nim, w niej otwiera się droga prowadząca do nowego stworzenia, którego oczekują wszystkie istoty stworzone" (7-8). Stworzenie, jak wyjaśnia dalej autor, związane jest z historią i kultem. W tym obszarze obraz zajmuje pozycję równoważną ze słowem. Funkcje obrazu, wyjaśnia autor książki, są zróżnicowane, jak zróżnicowane jest miejsce i charakter słowa w liturgii, co też było przedmiotem polemik, a nawet ostrych sprzeciwów ikonoklastów wobec wszelkich obrazów w Bizancjum, a powroty były znaczące w historii zachodniego chrześcijaństwa średniowiecznego i nowożytności.

Treść listu Jana Pawła II obejmuje obszerne zagadnienia historyczne Kościoła wschodniego, systemu władzy cesarskiej, uwarunkowań teologicznych wynikających z dogmatów: o Trójcy Świętej, o Chrystusie Synu Bożym i o Maryi Dziewicy Matce jako Theotokos. Dogmaty ogłoszone przez sobory konstantynopolitański II i efeski dawały niepodważalne podstawy dogmatyczne i liturgiczne dla tworzenia i kultu obrazów świętych. Dla Jana Pawła II tak ważne było podkreślenie niebezpieczeństwa dla istoty wiary chrześcijańskiej, jakie wynikało z ikonoklazmu - zakazu tworzenia obrazów. Podważane były fakty wcielenia i człowieczeństwa Chrystusa, zarazem Syna Bożego. Ikonoklazm, wprowadzając zakaz tworzenia obrazów religijnych, zachwiał całą podstawą liturgii, także teologią wzoru i podobieństwa wynikającą z Genesis.

Ikona oraz wizualizacja narracji Ewangelii i hagiografii miały już od VI wieku w Bizancjum, w kręgach klasztornych oraz pałacowych, zwłaszcza w Konstantynopolu, ugruntowaną formułę. Czytelnie określono założenia artystyczne, które nawiązując do tradycji antycznej, nie były tejże kopią. Wypracowano oryginalne modele obrazowe, które określały istotę dogmatu i treści ikony. Ikonoklazm w Europie podważał najgłębsze podstawy wiary i kultury chrześcijańskiej, ale był również zagrożeniem dla trwałości dogmatów wypracowanych na soborach wczesnego chrześcijaństwa i w pismach ojców Kościoła.

Opublikowany w roku 1987 list Ojca Świętego, wydobywając z odległej historii niegdysiejsze zagrożenia, naprowadza ku pytaniom o istotę rozumienia wizualizacji sztuki sakralnej jako nierozłącznego ogniwa słowa i liturgii, aktualnego w czasach współczesnych. Do zagłębienia się w istotę tego listu skłania fakt, że papież był po- 
wściągliwy w wypowiedziach dotyczących kwestii artystycznej wizualizacji plastycznych. W przeciwieństwie do słowa w rozumieniu dramatu, poezji, ogólnie rzecz biorąc - literatury. Sztuki wizualne są przekazem wiary historii świętej i etyki, natomiast forma komunikacji artystycznej i estetyka pozostają w obszarze oddalonym od głównych wypowiedzi (Jan Paweł II, „List do artystów” 490-501; por. Rogozińska 21-37)

1200. rocznica II Soboru Nicejskiego (rok 787) wyjątkowo uroczyście obchodzona była w Kościele łacińskim, czego wyrazem był list z 8 października 1987 r., skierowany przez kardynała sekretarza stanu do przewodniczącego Międzynarodowego Stowarzyszenia Historyków Soborów z okazji sympozjum zorganizowanego w Istambule, w którym uczestniczyli kardynałowie reprezentujący stolicę apostolską (L'Osservatore Romano). Z tej niezwykłej okazji ogłoszona została encyklika patriarchy Konstantynopola i Świętego Synodu z 14 września 1987 r.

Jak głęboko przeżywany był Sobór Nicejski II w owym czasie, czyli w drugiej połowie VIII wieku, w kręgu Bizancjum i w imperium Karola Wielkiego, świadczą dokumenty i pisma historyków. Głębokie były kontrowersje w obrębie życia religijnego oraz w sztuce VIII wieku, o czym świadczą studia badawcze i obszerne monografie na ten temat. Sobór zwołany został przez ówczesnych władców Bizancjum - cesarzową Irenę (752-803; cesarzowa w latach 797-802) i jej syna Konstantyna VI, którzy zaprosili papieża Hadriana I (772-795). Sobór potwierdził jego godność jako „tego, który przewodniczy na stolicy świętego i najczcigodniejszego Piotra Apostoła" (Jan Paweł II, Duodecimum saeculum 437). W soborze zwołanym w Nicei, nad morzem Marmara, w kościele Koimesis - Zaśnięcia Maryi, będącym wówczas centrum greckiej liturgii kultu Maryi, uczestniczyli przedstawiciele Kościoła rzymskiego, w którym kult obrazów był już mocno ugruntowany. Obecny był igumen z greckiego klasztoru św. Saby w Rzymie, zaproszono patriarchów Wschodu: Aleksandrii, Antiochii, terenów znajdujących się pod panowaniem islamu. Irena, nie będąc formalnie cesarzową, potrafiła przeforsować własne postanowienie dotyczące kultu obrazów, czym ugruntowała ortodoksję wschodnią. W dniu 11 marca 843 r., w pierwszą niedzielę Wielkiego Postu, opublikowano dokument synodalny, który potwierdził idee Soboru Nicejskiego II. Pierwsza niedziela Wielkiego Postu upamiętniła przezwyciężenie ikonoklazmu. Nazwano ją niedzielą ortodoksji. Tego dnia odbywały się uroczyste procesje, śpiewano hymny, odczytywano uroczyście Synodikon Ortodoksji, dokument, w którym ponowione zostało potępienie ikonoklazmu wraz z podaniem anatem przeciwko odstępcom (Świat Bizancjum 130).

Przekonaniem ikonofilów było istnienie ścisłego związku obrazu z jego prototy-

\footnotetext{
${ }^{1}$ Wszystkie teksty listów cytowanych w tym artykule pochodzą z wydania pt. Wybór listów Ojca Świętego Jana Pawła II; JAN PAwEe II, „List apostolski Duodecimum saeculum” 436-445.
} 
pem, dlatego ojcowie Soboru Nicejskiego II domagali się, aby imię świętego i nazwa sceny były umieszczone w inskrypcji na obrazie. Pierwotny wizerunek reprezentacyjnego popiersia Maryi musiał być ugruntowany tradycją, a nie wyobraźnią, dlatego nawiązywał do wizerunków rozpowszechnionych na monetach i medalach rzymskich ukazujących Wiktorię, boginię zwycięstwa, czczoną w takiej kompozycji formalnej od czasu panowania cesarza Maurycjusza (582-602) (Alteri 95-101).

Ikony o szczególnej mocy umieszczane były w cancelli, przegrodzie oddzielającej prezbiterium od nawy, tworząc w ten sposób zaczątek ikonostasu. Wizerunki tego typu miały skupić na sobie wzrok wchodzących do świątyni były przygotowaniem do modlitwy. W kościele bizantyńskim wypracowano duchowość związaną z taką łącznością wzroku wiernego i jego modlitwą skierowaną do Boga za pośrednictwem ikony, tym samym wizerunek malarski stał się szczególnie istotny w pobożności wschodniej (Belting 372).

Zagadnienie ikonoklazmu i prowadzone wokół tegoż polemiki pozwalają zrozumieć argumenty broniących obrazy, które stały się katalizatorem w całej serii konfliktów związanych z sytuacją zewnętrzną i wewnętrzną cesarstwa (Grabar; Culter i Spieser; źródła por. Brubaker i Haldon; Romano 133-153).

Powrót do obrazów nie tylko przywracał wizerunki, lecz także całe kompozycje i bogactwo realiów nawiązujących do klasycznych wizualizacji z aparatem mimesis, sztuki realizującej formy widzialne narracji ludzkich, krajobrazy z wąwozami skalnymi, urwiskami czy łagodnymi łąkami. Przykładem są miniatury Homilii Grzegorza z Nazjanzu, kodeksu powstałego w latach 880-803 dla cesarza Bazylego I i Eudoksji I (Paryż Bibl. Nat. gre. 510) (Brubaker). Krajobrazy nie stanowiły jedynie dekoracyjnego tła, lecz integralnie związane zostały z postaciami jako miejsce, które jest również dziełem Stwórcy. W takim znaczeniu stanowiły jedność znaczeniową z narracją postaciową, uzmysławiały jedność stworzenia, które pomaga wznieść się ku rzeczywistości spirytualnej. Równie precyzyjny artystyczny kunszt przejawiają miniatury Psałterza Paryskiego z pierwszej połowy X wieku (ms.gr; 139, Paryż, Biblioteka Narodowa) (Grabar 276). Ukazane tutaj postaci historyczne, np. Dawida, Goliata, proroka Izajasza, w uwarunkowaniach cielesnych nawiązujących do klasycznej sztuki, są równie zmysłowe, co personifikacje Nocy, Jutrzenki, Echa. Postaci zaczerpnięte $\mathrm{z}$ tradycji antycznej personifikują duchowe uwarunkowania całego, również cielesnego człowieka. Obfita, zmysłowa przyroda jest miejscem dla całej narracji. Ani ludzka cielesność, ani piękno przyrody nie budzą już lęku w kontekście przekazu religijnego. Do takich rozwiązań artystycznych przyczyniły się m.in. gruntowne polemiki i dogmatyczne dysputy nad relacją stworzenia do Stwórcy, człowieczeństwa i boskości Syna. Rozwinięto pogłębione interpretacje ludzkiego ciała, duszy i istot niebiańskich. Powrócono do patrystycznej hierarchii stworzenia zwierząt, przyrody, ziemi. Znane stanowiska ojców Kościoła, zwłaszcza 
św. Augustyna, były na nowo czytane i odnowione w kontekście nauczania, które rozwinęły w IX wieku zarówno kręgi dworskie, jak i zakonne. Okres 886-1025, nazywany w sztuce renesansem macedońskim, ożywiały nurty powrotu do źródeł, do greckiej tradycji, która inspirowała obrazy swoim klasycyzmem, nie ujmując niczego powadze doktrynalnej, co potwierdzają luksusowe rękopisy i ikony cesarskie. Splendor materialny, luksus wyrobów złotniczych, kości słoniowej, drogocennych kamieni, tkanin haftowanych złotem nie zakłócały duchowego wymiaru wizualizacji postaci boskich, wręcz pogłębiały transcendentny sens zmysłowości materii.

Ikonoklazm wymusił niejako nowe, pogłębione interpretacje funkcji sztuki, jej hierarchii w obrębie sacrum i jej udziału w życiu świeckim. Znane w antyku kategorie, takie jak światło, barwy, kształt, podjęto na nowo w interpretacji Bożego piękna objawienia i cech obecności Bożej, możliwej w doświadczeniu ludzkim. W tym zakresie estetykę Pisma Świętego wyjaśnił, posługując się greckim aparatem filozoficznym, Bazyli Wielki (329-379), doceniany w liście Ojca Świętego św. Jana Pawła II. Sztuka, podejmując wzory zmysłowe przyrody, nie jest tożsama z przyrodą, ale z ideą nadzmysłowego, duchowego piękna. Światem rządzi prawo Boże i Jemu podporządkowane jest prawo natury, w tym sensie jest możliwa partycypacja piękna stworzonego przez człowieka w pięknie boskim. Doceniano wiedzę i rangę znawstwa materiału jako gwaranta umiejętności artysty, jego opracowania zwłaszcza materiałów kosztownych i trudnych, np. trybowania blachy, złotnictwa, odlewnictwa monumentów, także tkactwa i skórnictwa w sztukach użytkowych.

Przesłanie listu Ojca Świętego obejmuje w swojej skrupulatnej syntezie ważne kwestie odnoszące się do historii cesarstwa bizantyńskiego, Kościoła wschodniego, jego przenikania się z dziedzictwem łacińskim. Polityczne uwikłania ukształtowały niejednoznaczny pogląd na temat obrazów w monarchii karolińskiej, mimo programu powrotu do idei cesarstwa rzymskiego. Przeszkodą w przyjęciu nowego rozumienia sztuki według zasad nicejskich był fakt objęcia władzy w roku 797 w cesarstwie wschodnim przez kobietę, cesarzową Irenę, czego nie mógł zaakceptować Zachód (Strzelczyk 93). Na tle współczesnych badań naukowych aktualne są kwestie ekumeniczne podjęte właśnie przez Ojca Świętego Jana Pawła II. Autor wskazał na zarzewie zaciekłego sporu o obrazy, który w latach 730-780 stał się przyczyną rozdarcia w obrębie cesarstwa za panowania cesarzy izauryjskich, Leona III i Konstantyna V, utrzymanego jeszcze w czasach panowania Leona V (814-843). Ruch ikonoklastów doprowadził wręcz do wrogości we wspólnocie chrześcijańskiej związanej jedną Biblią i Tradycją Kościoła. Wprowadzenie zamiast obrazów świętych portretów świeckich cesarzy, nawet jeżeli byli uznawani za najwyższą władzę kapłańską, którym oddawano uszanowanie, analogiczne z tym, jakie wypracowano wobec ikon, było zalążkiem wypełnionej herezjami przepaści między Wschodem a Zachodem. W centrum polemik podjętych przez ikonoklastów znalazły się dog- 
maty, zwłaszcza chrystologiczny, dotyczący boskiej natury Chrystusa, której - jak argumentowano - nie można unaocznić środkami malarskimi, ponieważ bóstwo jest niewyrażalne środkami zmysłowymi sztuki. Ukazywanie Chrystusa w ludzkiej postaci mogłoby być podważeniem boskości Syna Bożego w Jego człowieczeństwie. Rozbieżne stanowiska monofizytyzmu i nestorianizmu stały się argumentem za zakazem tworzenia wyobrażeń Chrystusa i postaci świętych.

Ojciec Święty, podejmując obszerną prezentację historycznego problemu, wskazał na konsekwencje ikonoklazmu: podważenie całej chrześcijańskiej nauki o Wcieleniu, głębokiej więzi między Bogiem a światem, między łaską a naturą, między objawieniem a paruzją, powtórnym przyjściem Chrystusa - Syna Bożego. W tym nurcie wypowiadał się przytaczany w Liście św. German (634-733), patriarcha Konstantynopola (715-730), który bronił tradycji i jej podstaw, antropologii dzieła stworzenia na podobieństwo Boże. Bronił racji ludzkiego oblicza Syna Bożego, który

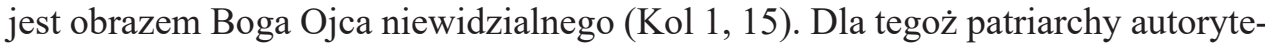
tem był św. Jan Ewangelista, którego ewangeliczne przesłanie było podłożem interpretacji, „Słowo stało się ciałem i zamieszkało wśród nas” (J 1, 14) oraz „Oto Baranek Boży, który gładzi grzechy świata” (Jan Paweł II, Duodecimum saeculum 442).

Papież rozwinął idee Soboru Nicejskiego ze względu na ich aktualność na Soborze Watykańskim II. Tam nawiązano do problematyki tradycji: Pisma jako tradycji pisanej i Tradycji niepisanej, będącej stałym odniesieniem wiary i dyscypliny Kościoła. Kwestia Tradycji podejmowana była przez wielkich doktorów Kościoła wschodniego: św. Jana Chryzostoma, św. Grzegorza z Nyssy, św. Cyryla Aleksandryjskiego, św. Grzegorza z Nazjanzu, a także św. Jana Damasceńskiego. Na ich autorytecie tworzone były zręby teologii łacińskiej, która mimo pewnych różnic, zasadniczo bazowała na interpretacji ojców wschodnich, szczególnie w kwestiach liturgicznych, interpretacji człowieczeństwa i boskości Chrystusa, dziewiczego poczęcia Syna Bożego oraz Trójcy Świętej. „Słowo Boże przez Chrystusa Pana i Ducha Świętego powierzone Apostołom ... obejmuje wszystko, co przyczynia się do prowadzenia świętego życia przez lud Boży i pomnożenia wiary" (444). Do tej definicji odwołał się Sobór Watykański II, wskazując na aktualne znaczenie niegdysiejszych postanowień II Soboru Nicejskiego, w których określono stanowisko w sprawie teologii obrazów. Ojcowie nicejscy oparli się na Tradycji i nauce ugruntowanej w Kościele, sformułowanej przez św. Bazylego (330-379), która przyświecać powinna współczesnym artystom, „cześć oddawana świętym obrazom odnosi się do ich pierwowzorów" (441). W Kościele łacińskim prawdę tę zdefiniował, rozwijając naukę ojców wschodnich, papież Grzegorz Wielki (540-604), precyzując funkcję sztuki, zwłaszcza plastyki. Przybliża ona wiarę tym, którzy nie potrafią czytać Biblii. Jak wyjaśnia tenże uczony papież, obrazy naprowadzają ku kontemplacji podobnie jak Pismo, prowadząc do adoracji wszechmocnej Trójcy Przenajświętszej. 
Papież Hadrian kontynuował ideę odwzorowania cielesności w obrazie:

... gdy patrzymy na obraz ukazujący ciało, które Syn Boży zechciał przyjąć dla naszego zbawienia, jego widzialne oblicze przyciąga nas i prowadzi naszą duszę ku niewidzialnemu majestatowi Boga. W ten sposób adorujemy i czcimy samego Odkupiciela, wysławiamy Go w duchu, albowiem napisane jest: Bóg jest duchem i dlatego my w duchu naszym sławimy Jego bóstwo (437).

Przesłanie to pojawia się w wielu listach i homiliach Ojca Świętego wygłaszanych w czasie pielgrzymek do różnych sanktuariów, m.in. szczególnie bliskiego mu sanktuarium Matki Bożej Jasnogórskiej.

Przełomowym wydarzeniem na miarę historyczną, potwierdzającym dotychczasowe dążenia ekumeniczne Ojca Świętego, których wyrazistym sygnałem był ów list z roku 1987, było przekazanie świętej ikony Kazańskiej przez papieża patriarsze Rosji Aleksemu II. Homilia Ojca Świętego zatytułowana Święta ikona powracająca na ziemię rosyjska, jest potwierdzeniem antropologii ikony jako Osoby Maryi z Dzieciątkiem powracającej do Cerkwi prawosławnej, która Ją przez wieki umiłowała (Homilia Święta ikona). Homilia pożegnalna wygłoszona w Auli Pawła VI prezentowała historię ikony zaginionej w ubiegłym stuleciu, która znalazła się w Watykanie i czuwała, jak powiedział papież, „nad moją codzienną pracą”. Modlitwie tej towarzyszyła 5-tysięczna grupa wiernych. W święto Zaśnięcia Maryi Panny, 28 sierpnia, w Soborze Uspieńskim na Kremlu odbyło się uroczyste powitanie Maryi. List Ojca Świętego Jana Pawła II odczytał kard. Walter Kasper. W tekście znalazły się określenia ikony jako osoby, która ,zaginęła w ubiegłym stuleciu, przemierzyła wiele krajów, na ponad 10 lat zatrzymała się w Fatimie, a od 10 lat dotarła do Watykanu" (Homilia Święta ikona). Ceremonia przekazania ikony Kazańskiej potwierdziła racje sformułowane na Soborze Nicejskim II, co podkreślił w swoim liście Ojciec Święty. Rozgraniczono ,prawdziwą adorację” (latreia), która odnosi się wyłącznie do boskiej natury, od „oddawania czci” postaciom ukazanym na ikonach (timatike proskynesis). Ten, kto pada na twarz przed obrazem, pada na twarz przed osobą (ipostaza), którą obraz ten wyobraża (Homilia Święta ikona).

Ojciec Święty dostrzegł problem powszechności obrazów, różnorodności ich form, od czasów wczesnych, średniowiecznych do nowożytnych i współczesnych, co dotyczy Kościoła zarówno wschodniego, jak i łacińskiego. Powracając do znaczenia Soboru Nicejskiego, przy wszelkich jego politycznych i społecznych uwikłaniach, papież wskazuje jednocześnie, że obrazy muszą zachować swoją godność formy i kompozycji oraz czci przez wiernych. Wtedy zachowuje się wobec obrazów należną im Tradycję. Jest ona zawarta w rezolucji Soboru Nicejskiego II. Tradycja znalazła się u podstawy jednoznacznie brzmiącej decyzji umieszczania „czcigodnych i świętych wizerunków w postaci barwnych obrazów, mozaik i innych w kościołach Bożych, na naczyniach i paramentach, na ścianach i na drew- 
nie, w domach i na ulicach. Dotyczy to zarówno wizerunków Pana naszego i Zbawiciela Jezusa Chrystusa, jak i Naszej Pani Niepokalanej, Najświętszej Theotokos, czcigodnych aniołów oraz wszystkich świętych i pobożnych ludzi" (Dokumenty soborów powszechnych $331 \mathrm{nn}$.). Wizerunki umieszczane w przestrzeni kościoła czy klasztoru nie były rozumiane jako sztuka lub dzieła sztuki, były one częścią integralną liturgii, w łączności ze słowem Ewangelii oraz modlitwami i pieśniami. W liście Ojca Świętego znalazło się potwierdzenie słów św. Nicefora I (758-829), patriarchy Konstantynopola (806-815), uczestnika soboru w Nicei, zaangażowanego na rzecz obrony Tradycji Kościoła, która obejmuje również ikony (Jan Paweł II, Duodecimum saeculum 442; Alexander).

Dostrzegając rangę postanowień Soboru Nicejskiego, Ojciec Święty Jan Paweł II wskazał w swoim liście na wynikające z dylematu ikonoklastów, daleko idące zagrożenia dla rozumienia istoty ciała ludzkiego stworzonego przez Boga i ciała Chrystusa Wcielonego jako Syna Bożego będącego obrazem Ojca. Z tego dogmatu wynikają kwestie zmartwychwstania ciała i życia wiecznego, co podważały herezje monofizyckie. Kwestie te, podejmowane w teologii pierwszych wschodnich ojców Kościoła, szczególnie Orygenesa, były głęboko rozpoznawane wśród ojców soboru zebranego w owym greckim klasztorze w Nicei. Rangę tego problemu w zachowaniu podstaw wiary podkreślił również Ojciec Święty Jan Paweł II, wskazując na granice między prawdziwą adoracją Boga i Osób Boskich a czcią oddawaną ikonom, wizerunkom ukazanym środkami materialnymi, malarskimi.

Kościół aprobuje ten rodzaj sztuki, ponieważ jest przeświadczony, że Bóg, który objawił się w Jezusie Chrystusie, rzeczywiście odkupił i uświęcił ciało oraz cały świat dostępny poznaniu zmysłowemu, aby człowiek mógł „wciąż się odnawiać według obrazu tego, Który go stworzył” (Kol 3, 10) (Jan Paweł II, Duodecimum saeculum 442-443).

Kościoły wschodni i łaciński, pomimo przyjęcia w całości postanowienia Soboru Nicejskiego, nie wyzwoliły się z zachwiania wobec prawdy o obrazie, zarówno w cesarstwie bizantyńskim, jak i cesarstwie Franków (w latach 825-843), na co wskazał Ojciec Święty. Papież wyjaśniał konieczność obrony obrazów podejmowanej przez Kościół także w późniejszych okresach historii średniowiecznej i nowożytnej, co potwierdzają sobory średniowieczne i trydencki. W tekście papieża najsilniej przewijają się orzeczenia Soboru Watykańskiego II dotyczące wizerunków, które ukazują tajemnicę odkupienia, wspierają w modlitwie i w życiu duchowym wiernych. Wizerunki są źródłem wiary, wyrazem potrzeby człowieka religijnego w oddawaniu czci Osobie Boskiej lub świętej ukazanej w jej wizerunku. Typ pobożności, czasem niesłusznie określany jako „obrazkowy”, jest świadectwem zachowania Tradycji, podobnie jak zachowuje się treść Biblii jako słowo Boże. 
List Ojca Świętego stanowi kwintesencję teologii ikony powstałej we wczesnym okresie życia Kościoła i zarazem antropologię ikony, która dała podstawy obrazom przeznaczonym do wnętrz sakralnych poświęconych liturgii i sakramentom. W tym obszarze antropologii teologicznej powstała wizualizacja oblicza zarówno w szerszym znaczeniu, w charakterystycznie ukazywanych twarzach postaci świętych i boskich, jak również Świętego Oblicza. Ta wizualizacja w różnych kontekstach znaczeniowych acheiropoietoi oraz odmiennych narracjach pasyjnych prowadzi do jednego toposu - oddającego boski i ludzki, zmysłowy i transcendentny sens obrazu. W ciągu dziejów sztuki chrześcijańskiej przewijały się kontradykcje wobec nicejskich założeń, ich teologicznej argumentacji. W sztuce europejskiej zwyciężyła koncepcja estetyczna twarzy, a nawet twarzy portretowej. Włączony został nawet krzyż jako przeciwstawienie narracji biblijnej w wystroju kościoła. Legitymizowany był przez ikonoklastów dla oddania czci jak samemu Chrystusowi, według Ewangelii św. Mateusza: „krzyż jest znakiem Syna Człowieczego, pojawi się na niebie podczas paruzji” (Mt 24, 30). Przykładem jest Kościół Zaśnięcia Najświętszej Panny Maryi w Nicei, który był świadkiem tej ambiwalencji. Monumentalny krzyż umieszczono w absydzie, usuwając pierwotną mozaikę Maryi Panny z Dzieciątkiem, następnie - po Soborze Nicejskim - ponownie umieszczono w absydzie stojącą Maryję z Dzieciątkiem (zniszczona w 1922 r.), usuwając krzyż (Belting 183). Podobna sytuacja nastąpiła w Konstantynopolu, w kościele św. Ireny. W absydzie, którą pierwotnie wypełniała postać Maryi, znalazł się monumentalny krzyż w mozaice absydowej z VIII wieku (Grabar 154 nn., il. 88). Krzyż potwierdzał tezy ikonoklastów, ponieważ, jak słusznie wskazywali, krzyż, a nie obraz, stał się miejscem i narzędziem zbawienia. Nadrzędne znaczenie krzyża ponad postacią świętą i ponad Świętym Obliczem podkreślali niektórzy teologowie karolińscy zachowujący tendencje ikonoklastów, co przekazano w Libri Carolini. Nawet biskup Teodulf z Orleanu, uczony autorytet Karola Wielkiego, umieścił w swojej kaplicy Arkę Przymierza.

Ikona, wyobrażając cielesną i duchową naturę Chrystusa, potrafi oddać tajemnicę podobieństwa, relacji Syna do Ojca w swojej boskiej naturze, a Boga, który stał się widzialny, w naturze ludzkiej. Paradoksalnie ascetyczna filozofia ikony, potwierdzona tezami soboru efeskiego, przywróciła porządek nadany przez Stwórcę całej naturze, tym samym prawo jej wizualizacji w sztuce, co potwierdzają cytowane powyżej przykłady miniatorskie powstałe w kodeksach dworskich. Ikona zespala Ojca i Syna w jednym wizerunku, który jest świadectwem osoby i jako osobie można okazać jej cześć. Godny podkreślenia jest także fakt, że teologowie bizantyńscy, broniąc ikon i zarazem ich kultu, starali się bronić przed ich nadużyciami. Teoria ikony, poniekąd także sztuki, podejmowana w rozważaniach teologicznych, dotykała filozofii platońskiej i w tym nurcie zachowała swoją ważność w późniejszych 
czasach nowożytnych. Jednym z pierwszych teologów ikony w tym aspekcie filozoficznym był Jan z Damaszku (675-749), który w klasztorze św. Sabasa pod Jerozolimą zgłębiał wcześniejsze pisma platończyków i ojców Kościoła pozostających w nurcie platońskim i neoplatońskim. Asceta uporządkował znaczenie i sens obrazów jako narzędzi służących przypominaniu dziejów zbawienia. Stąd obrazy narracyjne i historyczne nabrały równej rangi reprezentacyjnej. Dzięki wiedzy filozofii antycznej Święty potrafił jasno sformułować różnice w czci rozumianej w tradycji greckiej i w tradycji chrześcijańskiej. „Grecy Hellenes czynili bogami kamienie albo rzeźby, my zaś ustawiamy wizerunki prawdziwego Boga wcielonego w człowieka. ... Obrona tradycji to cel ikon, spór o ikony to spór o sposób odczytania źródeł" (Belting, supl. 7: Pierwsza teologia obrazu 574).

Problem „podobieństwa” podejmowany w dysputach Bizantyńczyków w obrębie interpretacji ikon nie został w tym miejscu wyczerpany. Znany był Ojcu Świętemu jako filozofowi i jako teologowi, ponieważ przewijał się w późniejszych okresach historii. Obraz Ojca w Synu wytworzony został z woli Ojca, w ikonach zaś chodzi o obraz wytworzony przez człowieka, sporządzony przez malarza na tablicy lub na innym podłożu. Obrazy te są odrębne i nieporównywalne. Platońska koncepcja wyjaśnia ideę podobieństwa analogią pieczęci i jej odcisku albo - jeszcze bardziej obrazowo - ciała materialnego i jego cienia. Tak do każdego prawzoru należy jakiś jego wizerunek. Zatem obraz nie jest rezultatem inwencji malarza, lecz aktem dokonanym tego, kto został na nim odwzorowany (Jan Paweł II, Duodecimum saeculum 444). Sprawność, inwencja, zdolności artysty, również szlachetność materiałów i pigmentów są istotnymi uwarunkowaniami w ukazaniu owego prawzoru, ale nie stanowią one jego istoty.

List Ojca Świętego pod znamiennym tytułem Duodecimum saeculum podejmuje ważne wydarzenie historyczne, jakim był II sobór w Nicei, który angażował wybitne umysły i władców politycznych w drugiej połowie VIII i w początkowym dziesięcioleciu wieku IX. W prace soboru włączone były główne centra teologiczne Wschodu i Zachodu stanowiące wspólne dziedzictwo wiary chrześcijańskiej, nie wyłączając kwestii politycznych. Cała treść listu wskazuje na cel, nie jest tylko przypomnieniem tamtych faktów z historii Kościoła i historii Europy. Nie jest syntezą ważnych idei. $\mathrm{Z}$ treści listu, w którym zawarte zostały bogate podstawy dogmatyczne i filozoficzne, emanuje doskonała synteza niezwykle bogatej literatury źródłowej zebranej w wielotomowych wydaniach naukowych, cytowanych w monografiach szczegółowych. 
List ma swoją klarowną osnowę, którą stanowi Sobór Nicejski II, wraz z wszystkimi jego najważniejszymi przyczynami zakazu i koniecznością powrotu do ikony dla ugruntowania wiary. List uwidacznia przejrzyście również wątki odnowione już na Soborze Watykańskim II, a odnoszące się do rozumienia funkcji i formy obrazów w Kościele współczesnym. Nie jest to wszak niegdysiejszy dramat prześladowań obrazów, zakaz wizualizacji osób boskich i świętych. Nie zachodzi konieczność alternatywnego wyboru: albo ikona, albo krzyż. Współczesność owładnęła (list napisany został w znamiennym roku 1987) niemoc duchowego wyrazu sztuki sakralnej i to jest troską Papieża. Autor wyjaśnia wprost:

\begin{abstract}
Pragnę w tym miejscu przypomnieć moim braciom w biskupstwie, że należy stanowczo zachować zwyczaj umieszczania w kościołach wizerunków świętych dla oddawania im czci przez wiernych i troszczyć się o powstawanie licznych i wartościowych dzieł sztuki kościelnej. Trzeba, aby również, podobnie jak w przeszłości, człowiek wierzący mógł odnajdywać w dziełach, które ukazują całą tajemnicę, w niczym jej nie przesłaniając, pomoc dla swojej modlitwy oraz wsparcie dla życia duchowego (444).
\end{abstract}

Ostateczne przesłanie, jakie wynika z końcowej frazy listu, stanowi dramatyczne ostrzeżenie wobec zagrożeń dla sztuki religijnej w czasach współczesnych, co wyraził Ojciec Święty słowami:

\begin{abstract}
Ponowne odkrywanie wartości chrześcijańskiej sztuki może być również pomocą w uświadomieniu sobie konieczności przeciwstawienia się depersonalizującym skutkom oddziaływania tak wielu obrazów, które docierają do nas za pośrednictwem reklamy i środków przekazu, uzależniając od siebie nasze życie religijne i powodując jego degradację. Sztuka chrześcijańska bowiem kieruje nasz wzrok ku niewidzialnemu Innemu i wprowadza w rzeczywistość świata duchowego i eschatologicznego (445; por. Sobór Watykański II, Konstytucja Gaudium et spes 570 nn.).
\end{abstract}

W odrębnym studium zaprezentowane zostaną badania tekstów innych listów i homilii Ojca Świętego, tutaj nie przytaczanych, w których zawarta została troska o współczesny wyraz sztuk plastycznych w wystroju współczesnych kościołów, w pełni realizujących zalecenia Soboru Watykańskiego II, tym samym zachowujących - konserwujących Tradycję Kościoła jako drugie skrzydło Pisma Świętego, dla podtrzymania wiary.

\title{
BIBLIOGRAFIA
}

Alexander, Paul J. The Patriarch Nicephorus of Constantinople. Ecclesiastical Policy and Image Worship in the Byzantine Empire. Clarendon Press, 1958.

Alteri, Giovanni. «Immagini della storia sulle monete byzantine.» Splendori di Bisanzio. Testimonianze e riflessi d'arte e cultura bizantina nelle chiese d'Italia, Giovanni Morello Fabbri, 1990, ss. 71-83. 
Belting, Hans. Obraz i kult. Historia obrazu przed epoka sztuki. Przeł. Tadeusz Zatorski, Wydawnictwo Słowo/Obraz Terytoria, 2010.

Brubaker, Leslie. Vision and Meaning in Ninth-Century Byzantium. Image as Exegesis in the Homilies of Gregory of Nazianzus. Cambridge University Press, 1998.

BRUBAKER, Leslie, and John F. Haldon. Byzantium in the Iconoclast Era (c. 680-850). The Sources. An Annotated Survey. Ashgate, 2001.

BüCHSEL, Martin, and Rebecca Müller. Intellektualisierung und Mystifizierung mittelalterlicher Kunst. „Kultbild“. Revision eines Begriffs. Mann 2010.

Culter, Anthony, and Jean-Michael Spieser, Byzance médiévale. 700-1204. Gallimard, 1996.

Dokumenty soborów powszechnych, oprac. Arkadiusz Baron i Henryk Pietras, przeł. Teresa Wnętrzak, Wydawnictwo WAM, 2001.

GrabAR, André. Les voies de la création en iconographie chrétienne. Antiquité et moyen âge. Flammarion, 1994.

Grabar, André. L'iconoclasme byzantin. Le dossier archéologique. Flammarion, 1984.

Hryniewicz, Wacław, ks., Karol Karski, i ks. Henryk Paprocki. Credo. Symbol naszej wiary. Społeczny Instytut Wydawniczy Znak, 2009.

JAN Pawee II. Dzieła zebrane, t. 14: Homilie i przemówienia okolicznościowe. Wydawnictwo M, 2010.

JAN PAWEe II. „List apostolski «Duodecimum saeculum» z okazji 1200. rocznicy Soboru Nicejskiego II" Jan Paweł II. Dzieła, t. 3: Listy, t. 2, Wydawnictwo M, 2009, ss. 436-445.

JAN PAwEe II. „List apostolski «A Concilio Constantinopolitano» z okazji 1600 rocznicy I Soboru Konstantynopolitańskiego i 1550 rocznicy Soboru Efeskiego”. Jan Paweł II. Dzieła, t. 3: Listy, Wydawnictwo M, 2009.

Konstytucja duszpasterska o Kościele w świecie współczesnym „, Gaudium et spes”. Sobór Watykański II. Konstytucje. Dekrety. Deklaracje. Tekst Polski. Nowe Ttumaczenie, red. Maria Przybył, Pallottinum, 2002, s. 526-605.

RatZinger, Josef. Der Geist der Liturgie. Eine Einführung. Herder, 2000, wyd. pol. Duch liturgii. Przeł. Eliza Pieciul, Wydawnictwo AA, 2005.

RogoziŃsKa, Renata. „«Wyjdzie z zamętu świat ducha». Myśl estetyczna Jana Pawła II a sztuka współczesna". Bo piękno na to jest, by zachwycało. Jan Pawet II w kulturze polskiej, red. Waldemar Chrostowski, Księgarnia św. Wojciecha, 2004, ss. 21-37.

Romano, Serena. «Rom und die Ikonen. Überlegungen zu Monument und Dokument im Mittelalter». Intellektualisierung und Mystifizierung mittelalterlicher Kunst. ,,Kultbild“. Revision eines Begriffs, hrsg. von Martin Büchsel, Rebecca Müller, Mann, 2010, z. 133-154.

StrzelczyK, Jerzy. Historia powszechna - średniowiecze. Wydawnictwo Poznańskie, 2008.

Świat Bizancjum, t. 2: Cesarstwo Bizantyńskie 641-1204, red. Jean-Claud Cheynet, przekł. Andrzej Graboń, Wydawnictwo WAM, 2011.

Wybór listów Ojca Świętego Jana Pawła II, red. Piotr Słabek, i Jacek Jękot, Wydawnictwo św. Stanisława B.M. Archidiecezji Krakowskiej, Wydawnictwo „M”, 1997.

\section{LIST APOSTOLSKI DUODECIMUM SAECULUM \\ OJCA ŚWIĘTEGO ŚW. JANA PAWŁA II \\ Z OKAZJI TYSIĄC DWUSETNEJ ROCZNICY SOBORU NICEJSKIEGO II MIEJSCE IKONY W WIERZE I ROZUMIENIU ŚW. JANA PAWŁA II}

Streszczenie

List Ojca Świętego Jana Pawła II napisany w Rzymie, w roku 1987, w dziesiątym roku pontyfikatu, 4 grudnia, w dniu liturgicznego wspomnienia św. Jana Damasceńskiego, doktora Kościoła w 1200 rocznicę zakończenia sporu o ikony, ma istotne znaczenie w programie ekumenizmu Papieża. 
Wskazywał wiele kierunków dialogu z różnymi religiami, jednak największą troską było porozumienie z Kościołem prawosławnym, co potwierdzają listy oraz inne dokumenty Ojca Świętego przytaczane w niniejszej pracy. Istotne było zachowanie tradycji Kościoła, w którym nieodłącznym ogniwem dla praktyk religijnych słowa, modlitwy i pieśni był obraz. Surowy zakaz wprowadzony przez ikonoklazm podważał nie tylko artystyczne tradycje obrazów, lecz także sięgał do podstaw dogmatów Wcielenia Chrystusa i Matki Dziewicy Maryi Panny jako Theotokos. Zakaz był zagrożeniem dla ikon, ale też dla istoty wiary chrześcijańskiej. Papież podkreślił w swoim Liście rolę Soboru Nicejskiego II, który przywrócił ikony oraz zapewnił ich pogłębione znaczenie dla kultu wiernych w ugruntowaniu wiary. Ojciec Święty wskazał również związek z Soborem Watykańskim II odnoszącym się do rozumienia funkcji i formy obrazów w Kościele współczesnym. Współczesność owładnęła niemoc duchowego wyrazu sztuki sakralnej co stanowi troskę Papieża. List jest dramatycznym ostrzeżeniem wobec zagrożeń dla sztuki religijnej w czasach współczesnych, które Ojciec Święty wyraził słowami „Ponowne odkrywanie wartości chrześcijańskiej sztuki może być również pomocą w uświadomieniu sobie konieczności przeciwstawienia się depersonalizującym skutkom oddziaływania tak wielu obrazów".

Słowa kluczowe: ikona; obraz; ikonoklazm; sztuka sakralna; ikona - kult i wiara.

\section{THE APOSTOLIC LETTER DUODECIMUM SAECULUM \\ OF THE HOLY FATHER JOHN PAUL II ON THE TWELFTH CENTENARY \\ OF THE SECOND COUNCIL OF NICAEA \\ THE MEANING OF THE ICON IN THE FAITH AND UNDERSTANDING \\ OF JOHN PAUL II}

Sum mary

The letter of the Holy Father John Paul II written in Rome in 1987, in the tenth year of His pontificate, on December $4^{\text {th }}$, on the day of memorial of Saint John Damascene, the doctor of the Church, on the Twelfth Centenary of finishing the controversy over the icon, is of great importance for the Pope's program of ecumenism. The Holy Father indicated various directions of the dialogue, however, the one of the utmost importance concerned the agreement with the Orthodox Church, which was confirmed in the letters and in His other documents quoted in this paper. The image used to be essential for religious practice, for illustrating the word of prayer and of the song, in order to preserve the tradition of the Church. The strict prohibition introduced by the iconoclasm depreciated not only the artistic tradition of paintings but also the basic dogmas of Christ's Incarnation and the one which introduced Virgin Mary as the Theotokos (the God-bearer). The ban constituted a threat not only for the icons but also for the Christian faith. In His Letter, the Pope underlined the important role of the Second Council of Nicaea which reintroduced icons and maintained and deepened the meaning of the cult in the faith of believers. Furthermore, the Holy Father indicated the connection with the Second Vatican Council in understanding the function and form of images in contemporary Church. Contemporary trends are overwhelmed by the impotence of the spiritual expression of sacral art, which is a great concern for the Pope. The Letter is, therefore, a dramatic warning of the threats for religious art in contemporary time, expressed by the Holy Father with these words: 'The rediscovery of the Christian icon will also help in raising the awareness of the urgency of reacting against the depersonalizing and at times degrading effects of the many images that condition our lives in advertisements and the media.' (DS, 11).

Keywords: icon; image; iconoclasm; sacral art; icon - cult in the faith. 